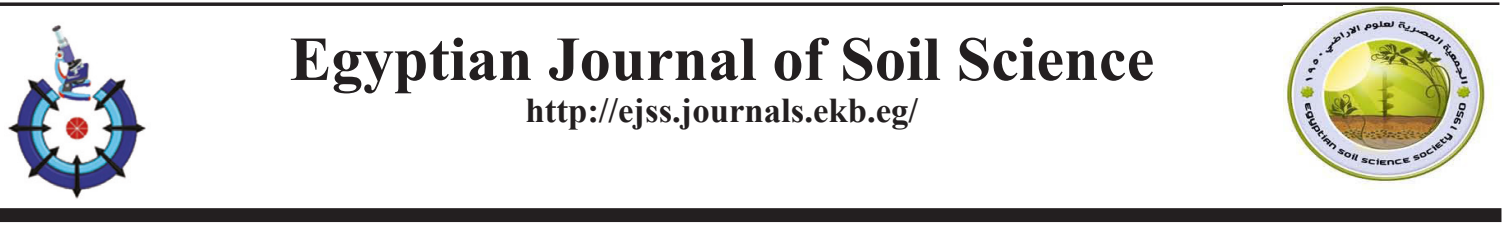

\title{
Equilibrium Content between Nitrogen and Phosphorus for Lettuce (Lactuca sativa L.) Grown in A Clay Soil
}

\author{
Tarek M. Younis ${ }^{1}$, Shaimaa H. Abd-EIrahman ${ }^{2 *}$ and Mohamed A.A. Abdrabbo ${ }^{1}$ \\ ${ }^{1}$ Central Laboratory for Agricultural Climate 12411, Agricultural Research Center, \\ Egypt \\ ${ }^{2}$ Soil and Water Department, Faculty of Agriculture 11241, Ain Shams University, \\ Egypt
}

\begin{abstract}
$\mathbf{T}$ HIS study aims to investigate the effect of different nitrogen concentrations $\left(60,120\right.$ and $\left.180 \mathrm{mg} \mathrm{L}^{-1}\right)$ applied in the form of ammonium nitrate $\left(\mathrm{NH}_{4} \mathrm{NO}_{3}\right)$ through fertigation and, also, phosphorus concentrations $\left(15,35\right.$ and $\left.55 \mathrm{mg} \mathrm{L}^{-1}\right)$ in the form of phosphoric acid $\left(\mathrm{H}_{3} \mathrm{PO}_{4}\right)$, individually or in combination with each other,on the growth parameters and yield of lettuce plants (Lactuca sativa L.), as well as nitrate accumulation in plant tissues. The investigations were conducted under the field conditions during the two growing seasons of 2019/2020 and 2020/2021 at the experimental farm of Dokki site, Giza Governorate, Egypt, following a split plot design. Obtained results indicated that increasing $\mathrm{N}$ supplies up to $180 \mathrm{mg} \mathrm{L}^{-1}$ led to concurrent increase in the vegetative growth characters (i.e., plant height, stem diameter, number of leaves per plant and chlorophyll content) of lettuce plants. While the lowest growth and productivity of plants were obtained by applying $60 \mathrm{mg} \mathrm{N} \mathrm{L}^{-1}$. Regarding the effects of $\mathrm{P}$ additions, increasing P supply up to $55 \mathrm{mg} \mathrm{L}^{-1}$ increased the growth and productivity of plants during both studied seasons. Interaction effect between $\mathrm{N}$ and $\mathrm{P}$ levels indicated that 180 $\mathrm{mg} \mathrm{N} \mathrm{L}{ }^{-1}$ combined with $55 \mathrm{mg} \mathrm{P} \mathrm{L}^{-1}$ gave the highest lettuce productivity followed by $180 \mathrm{mg} \mathrm{N} \mathrm{L}^{-1}$ combined with $35 \mathrm{mg} \mathrm{P} \mathrm{L}^{-1}$. The weight of lettuce head took the same trend of vegetative growth. The chemical analyses revealed that increase $\mathrm{N}$ dose led to increase the content of $\mathrm{N}, \mathrm{K}, \mathrm{Ca}$ and $\mathrm{Mg}$ as well as $\mathrm{N}_{-} \mathrm{NO}_{3}{ }^{-}$in plant tissues. Increase $\mathrm{P}$ level led to increase the $\mathrm{P}$ content. Finally, increase $\mathrm{P}$ level led

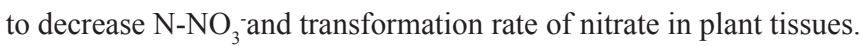

Keywords: Fertigation, Nitrogen, Phosphorus, Lettuce yield, Nutrient equilibrium, Nitrate accumulation.

\section{Introduction}

Excess $\mathrm{N}$ fertilization may decrease plant productivity and, also, may harm human health through accumulation of nitrate in the edible plant parts (Parente et al., 2006; Farag et al., 2013 and El-Dissoky, 2019). Leafy vegetable crops especially lettuce may accumulate $\mathrm{NO}_{3}^{-}$ ions when applying $\mathrm{N}$ in high doses (Prasad and Chetty, 2008), despite its short cultivation cycle. Moreover, $\mathrm{NO}_{3}^{-}$accumulation in lettuce leaves may have adverse impacts on climate changes and increase greenhouse gas emissions (Farag and Abd-Elrahman, 2016; Abd-Elrahman \& GadElmoula, 2017 and Elbasiouny and Elbehiry,
2019). Therefore, application of $\mathrm{N}$ fertilization in lettuce fields should consider not only farming economics but also the market preference and human health as well as environmental hazards issues (Schenk, 2006). Low $\mathrm{N}$ inputs induce metabolic imbalance within plants and, also, limits the synthesis of amino acids and proteins, thereby affect negatively on photosynthesis, growth, and chemical composition of the plant tissue (Liao et al., 2019). This may lessen plant growth especially in early growth stage and, also, delay flowering (Burns, 1996 and Moursy et al., 2019). Thus, timing and the dose of $\mathrm{N}$-application may have direct impacts on fruit yield quantity and quality (Heidari and Mohammad, 2012). 
Phosphorus, as an essential nutrient for all higher plants, is playing a vital role in enhancing plant growth and increasing yield with better quality (Khalifa, 2019). It is involved in many key plant functions, including photosynthesis, energy transfer molecules (ATP, ADP and AMP), transformation of sugars and starches, nutrient movement within the plant tissues and transfer of genetic characteristics from one generation to the next (Hammouda et al., 2019).

Studies had focused on the effect of applying different levels of $\mathrm{N}$, forms, and the time and way of application to leafy crops, as well as nitrate accumulation (Corradini et al., 2018 and Tabaglio et al., 2020). Less studies had pointed to the effects of $\mathrm{P}$ on the growth and yield of leafy crops and its effect on $\mathrm{NO}_{3}^{-}$accumulation rate inside the plants' tissues (Sadeghi et al., 2009). Therefore, further studies are needed in this concern. Ahmed et al. (2000) found significant reductions in nitrate contents inside plant tissues due to an increase in P fertilization rate. Inorganic $\mathrm{P}$ inside the plant is necessary for the metabolism and storage of nitrate, but high concentrations of it inhibit enzyme reactions, accelerate the growth, and the growth is accompanied by a decrease in nitrate uptake and accumulation (Buwalda and Warmenhoven, 1999).

Plant growth in the presence of $\mathrm{N}$ and $\mathrm{P}$ being considered most important because of their function role inside the plant and the large amount required for proper plant growth. Although soil provides most of these nutrients, reserves are limited, and fertilizer additions are necessary to maintain adequate nutrition. The use of fertilizers in crop production is critical to improve production efficiency for sustainable feeding of an ever-increasing population (Du et al., 2009; Sarkar et al., 2021). Thus, the current study aimed to investigate the proper quantity and equilibrium between $\mathrm{N}$ and $\mathrm{P}$ for good and healthy production of lettuce plants grown on a clay soil.

\section{Materials and Methods}

\section{Experimental site}

A field experiment was carried out during two successive seasons of 2019/2020 and 2020/2021 at the experimental farm of Central Laboratory for Agricultural Climate, Dokki, Agricultural Research Center, Giza governorate, Egypt. The coordinate of the farm is $30.04588 \mathrm{~N}$, and 31.20463 E. Table 1 illustrates the climatic conditions for the farm location during the experiment. Data were collected from an automated weather station installed in the farm location. The investigated soil was a clayey one, Vertic Torrifluvents (according to Soil Survey Staff, 2010), and its physicochemical properties were determined, before cultivation, by the standard methods outlined by Cottenie et al. (1982) and the obtained results are presented in Table 2.The Nile River water is the source of irrigation water; the EC of water was $0.38 \mathrm{dS} \mathrm{m}^{-1}$. Chemical composition of the water used for irrigation are presented in Table 3 .

\section{Experimental design and procedures}

The experimental design was a split plot design, included three $\mathrm{N}$ levels, i.e., 60, 120 and $180 \mathrm{mg} \mathrm{L}^{-1}$ located at the main plots as well as three P levels, i.e., 15,35 and $55 \mathrm{mg} \mathrm{L}^{-1}$ which located as sub-plots. These applications were applied through fertigation system either individually or in combination with each other. Nitrogen was added in the form of ammonium nitrate $\left(\mathrm{NH}_{4} \mathrm{NO}_{3}, 33 \% \mathrm{~N}\right)$; $\mathrm{P}$ levels in the form of $\mathrm{P}_{2} \mathrm{O}_{5}$ was applied as phosphoric acid- $85 \% \mathrm{H}_{3} \mathrm{PO}_{4}$ $\left(61 \% \mathrm{P}_{2} \mathrm{O}_{5}\right)$. Seeds of iceberg lettuce (Lactuca sativa var. capitata L.) cv. Chianti were sown on $13^{\text {th }}$ and $16^{\text {th }}$ September in polystyrene trays. Dates of transplanting were November $2^{\text {nd }}$ and $5^{\text {th }}$ of 2019 and 2020, for the first and the second seasons, respectively. The plants were cultivated in raised beds with $1 \mathrm{~m}$ width and $40 \mathrm{~m}$ length. Each bed represented one of the $\mathrm{N}$ levels (i.e., 60, 120 and $180 \mathrm{mg} \mathrm{L}^{-1}$ ). Each raised bed contained the different $P$ levels (i.e., 15,35 and $55 \mathrm{mg} \mathrm{L}^{-1}$ ). The experimental plot area was $120 \mathrm{~m}^{2}$ and all treatments were conducted in triplicates. Fertilizer tank was used for injecting the different $\mathrm{N}$ and $\mathrm{P}$ levels.In addition, each raised bed contained two rows of lettuce irrigated by one lateral dripper with discharge $4 \mathrm{~L} \mathrm{~h}^{-1}$. The in-row distance between each two plants is $30 \mathrm{~cm}$. Common cultural practices were used for lettuce production according to recommended practices for lettuce in the commercial fields.

\section{Measurements}

Samples of three plants were randomly harvested at 50 days from planting to determine their fresh and dry weights, as well as plant height, stem diameter and number of leaves per plant. Total chlorophyll was also estimated in the plant samples as a SPAD value as reported by Minolta (1989). The yield of lettuce was harvested after 70 days from transplanting. Total dry weight was determined after oven-drying the samples at 65 ${ }^{\circ} \mathrm{C}$ for $48 \mathrm{hr}$. Dried plant leaves were digested 
in $\mathrm{H}_{2} \mathrm{SO}_{4} / \mathrm{H}_{2} \mathrm{O}_{2}$ mixture according to the method described by Chapman and Pratt (1961), and the macro-nutrient, i.e., N, N-NO ${ }_{3}^{-}, \mathrm{P}, \mathrm{K}, \mathrm{Ca}$ and $\mathrm{Mg}$ were determined.Total $\mathrm{N}$ and $\mathrm{N}^{-} \mathrm{NO}_{3}{ }^{-}$were determined using Kjeldahl method according to the procedure outlined by Chapman and Pratt (1961). Phosphorus content was determined using Spectrophotometer according to Watanabe and Olsen (1965). Potassium content was measured using Flame photometer as outlined by Chapman and Pratt (1961). Calcium and magnesium were determined by EDTA according to the method that described by Derderian (1961).

Accumulation rate $(\%)$ of nitrate was computed as follows:

Accumulation rate, $\%=$ (Transformation rate)

\section{Statistical analysis}

Analysis of data was done using ANOVA program for statistical analysis. The differences among means for all traits were tested for significance at 5\% level of probability using Duncan's multiple range test (SAS, 2006).

TABLE 1. Meteorological data for Dokki site, Egypt during lettuce growing seasons of 2019/2020 and 2020/2021

\begin{tabular}{|c|c|c|c|c|c|c|c|}
\hline & \multicolumn{2}{|c|}{ Air Temp. $\left({ }^{\circ} \mathbf{C}\right)$} & \multirow{2}{*}{$\begin{array}{c}\text { RH (\%) } \\
\text { Avg. }\end{array}$} & \multirow{2}{*}{$\begin{array}{r}\text { Precipitation } \\
\text { Sum. (mm) }\end{array}$} & \multirow{2}{*}{$\begin{array}{l}\text { Wind Speed } \\
\text { Avg. }\left(\mathrm{m} \mathrm{s}^{-1}\right)\end{array}$} & \multirow{2}{*}{$\begin{array}{l}\text { Soil Temp. } \\
\text { Avg. }\left({ }^{\circ} \mathrm{C}\right)\end{array}$} & \multirow{2}{*}{$\begin{array}{c}\text { ET }_{0}(\mathrm{~mm}) \\
\text { Avg. }\end{array}$} \\
\hline & Max. & Min. & & & & & \\
\hline \multicolumn{8}{|c|}{$1^{\text {st }}$ season } \\
\hline Nov. 2019 & 28.9 & 10.8 & 57.9 & 11.6 & 0.30 & 21.7 & 3.20 \\
\hline Dec. 2019 & 21.6 & 6.60 & 56.5 & 10.7 & 0.50 & 16.5 & 2.60 \\
\hline Jan. 2020 & 17.8 & 4.20 & 59.6 & 3.20 & 0.50 & 13.4 & 2.10 \\
\hline Feb. 2020 & 19.6 & 5.70 & 57.2 & 6.90 & 0.40 & 15.2 & 2.40 \\
\hline \multicolumn{8}{|c|}{$2^{\text {nd }}$ season } \\
\hline Nov. 2020 & 27.6 & 10.3 & 58.2 & 7.40 & 0.40 & 20.2 & 3.10 \\
\hline Dec. 2020 & 23.1 & 8.80 & 58.8 & 6.00 & 0.20 & 16.8 & 2.80 \\
\hline Jan. 2021 & 18.3 & 5.50 & 58.8 & 3.80 & 0.40 & 16.4 & 2.20 \\
\hline Feb. 2021 & 20.9 & 5.50 & 57.8 & 1.60 & 0.50 & 16.6 & 2.50 \\
\hline
\end{tabular}

TABLE 2. Some physical and chemical properties of the experimental soil $(0-20 \mathrm{~cm})$

\begin{tabular}{|c|c|c|c|c|c|c|c|c|}
\hline \multicolumn{5}{|c|}{ Physical Property } & \multicolumn{4}{|c|}{ Water status, \% } \\
\hline Sand, \% & Silt, \% & Clay, \% & $\begin{array}{c}\text { Textural } \\
\text { class }\end{array}$ & BD $\mathrm{Mg} \mathrm{m}^{-3}$ & SP & FC & WP & AW \\
\hline 15.7 & 24.7 & 59.6 & Clay & 1.36 & 92.4 & 55.3 & 30.1 & 25.2 \\
\hline \multicolumn{9}{|c|}{ Chemical property } \\
\hline \multirow{2}{*}{$\begin{array}{c}\mathrm{pH} \\
\text { (Soil paste) }\end{array}$} & \multirow{2}{*}{$\begin{array}{c}\mathrm{EC}_{\mathrm{e}} \\
\mathrm{dS} \mathrm{m}^{-1}\end{array}$} & \multicolumn{7}{|c|}{ Soluble ions, $\operatorname{mmol}_{\mathfrak{c}} \mathbf{L}^{-1}$} \\
\hline & & $\mathrm{Ca}^{2+}$ & $\mathrm{Mg}^{2+}$ & $\mathrm{Na}^{+}$ & $\mathbf{K}^{+}$ & $\mathrm{HCO}_{3}^{-}$ & $\mathrm{Cl}^{-}$ & $\mathrm{SO}_{4}^{2-}$ \\
\hline 7.43 & 2.74 & 11.2 & 7.88 & 11.9 & 5.96 & 7.10 & 13.2 & 14.2 \\
\hline
\end{tabular}

$\overline{\text { Carbonate ions were not detected. BD means bulk density, SP means saturation percentage, FC means field capacity, WP }}$ means welting point, and AW means available water. 
TABLE 3. Chemical composition of the water used for irrigation.

\begin{tabular}{|c|c|c|c|c|c|c|c|c|c|}
\hline \multirow{2}{*}{$\mathbf{p H}$} & \multirow{2}{*}{$\begin{array}{c}E C_{w} \\
d S m^{-1}\end{array}$} & \multicolumn{8}{|c|}{ Soluble ions, meq $\mathrm{L}^{-1}$} \\
\hline & & $\mathrm{Ca}^{2+}$ & $\mathrm{Mg}^{2+}$ & $\mathrm{Na}^{+}$ & $\mathbf{K}^{+}$ & $\mathrm{CO}_{3}{ }^{2-}$ & $\mathrm{HCO}_{3}^{-}$ & $\mathrm{Cl}^{-}$ & $\mathrm{SO}_{4}^{2-}$ \\
\hline 7.23 & 0.38 & 1.55 & 1.08 & 0.98 & 0.19 & n.d.* & 2.08 & 1.25 & 0.47 \\
\hline
\end{tabular}

*n.d. means not detected.

\section{$\underline{\text { Results and Discussion }}$}

\section{Vegetative growth characters}

Data in Table 4 showed the vegetative characteristics of lettuce under different levels of $\mathrm{N}$ and $\mathrm{P}$ during the two studied seasons. Regarding the $\mathrm{N}$ level data indicated that the highest $\mathrm{N}$ level (180 $\mathrm{mg} \mathrm{L}^{-1}$ ) gave the highest lettuce growth during the two seasons. The treatment of $120 \mathrm{mg}$ $\mathrm{N} \mathrm{L}^{-1}$ came in the second order, by about 6.90 , $7.84,8.82,3.31,9.40$, and $7.66 \%$ reduction during the first season, and 9.34, 11.2, 10.1, 3.03, 7.22, and $8.19 \%$ reduction during the second season, as compared to the values given by applying the treatment of $180 \mathrm{mg} \mathrm{N} \mathrm{L}^{-1}$ for the studied vegetative growth parameters, i.e., fresh and dry weights, plant height, stem diameter, number of leaves per plant, and chlorophyll content, respectively. While the lowest $\mathrm{N}$ level gave the lowest lettuce growth.

Referring to the different levels of $\mathrm{P}$ for lettuce crop which are cultivated in clay soil, increasing P level up to $55 \mathrm{mg} \mathrm{L}^{-1}$ led to concurrent increase in the vegetative growth during both studied seasons. The interaction effect showed that the highest $\mathrm{N}$ level combined with different $\mathrm{P}$ levels led to increase vegetative growth. The $180 \mathrm{mg}$ $\mathrm{L}^{-1}$ of $\mathrm{N}$ combined with $55 \mathrm{mg} \mathrm{L}^{-1}$ of $\mathrm{P}$ gave the highest vegetative growth during both studied seasons followed by $180 \mathrm{mg} \mathrm{L}^{-1}$ of $\mathrm{N}$ combined with $35 \mathrm{mg} \mathrm{P} \mathrm{L}{ }^{-1}$, while the lowest interaction value was obtained by the lowest $\mathrm{N}$ level (60 $\mathrm{mg} \mathrm{L}^{-1}$ ) combined with different $\mathrm{P}$ levels. These results agreed with those obtained by Johnstone et al. (2005); Hoque et al. (2010); Farag et al. (2013); Djidonou and Leskovar (2019) about the effect of $\mathrm{N}$ and $\mathrm{P}$ fertilizers on the vegetative growth characters of lettuce plants.

\section{Yield}

Regarding the $\mathrm{N}$ level treatments, $180 \mathrm{mg} \mathrm{N}$ $\mathrm{L}^{-1}$ produced the significant highest lettuce heads during the two seasons. The treatment of $120 \mathrm{mg}$ $\mathrm{N} \mathrm{L}^{-1}$ came in the second order, while applying 60 $\mathrm{mg} \mathrm{N} \mathrm{L}^{-1}$ produced the lowest lettuce yield (Table 4). Regarding $\mathrm{P}$ levels (Table 4), the obtained results revealed that $55 \mathrm{mg} \mathrm{P} \mathrm{L}^{-1}$ gave the highest lettuce productivity in the two growing seasons. Lettuce production is reduced with reducing $\mathrm{P}$ concentration in the fertigation system. The lowest lettuce heads yield was obtained by $15 \mathrm{mg} \mathrm{L}^{-1}$ of $\mathrm{P}$ during the two studied seasons. Interaction effect between $\mathrm{N}$ and P levels (Table 4) was significant during the two investigated growing seasons. The lowest lettuce head was obtained by the lowest $\mathrm{N}$ level $\left(60 \mathrm{mg} \mathrm{L}^{-1}\right)$ combined with different $\mathrm{P}$ levels. Increasing $\mathrm{N}$ levels from 60 to $120 \mathrm{mg}$ $\mathrm{L}^{-1}$ led to increase yield sharply especially with moderate $\left(35 \mathrm{mg} \mathrm{L}^{-1}\right)$ or high $\left(60 \mathrm{mg} \mathrm{L}^{-1}\right) \mathrm{P}$ levels. The highest $\mathrm{N}$ level $\left(180 \mathrm{mg} \mathrm{L}^{-1}\right)$ gave the highest lettuce heads combined with different $\mathrm{P}$ levels.

Nitrogen is an essential nutrient for plant growth and development during cell division and enlargement phases of growth. Razaq et al. (2017) reported that $\mathrm{N}$ accelerate vigorous growth and its low rate than plant need leads to decline growth and low production. Saleh et al. (2016) stated that plant productivity increased as $\mathrm{N}$ dose increased up to $360 \mathrm{~kg} \mathrm{ha}^{-1}$. The better yield under higher supply of $\mathrm{N}$ was probably due to increasing the photosynthetic and uptake rates, which leads to an increase in the vegetative growth and heads yield of lettuce (Sarkar et al., 2021). With higher N rates, growth and yield increased due to dependent relationship between $\mathrm{N}$ and carbohydrates exist inside the plant (Djidonou and Leskovar, 2019) which led to increase the content of carbohydrates and proteins that considered as the final products of photosynthesis and metabolic activities.

Lettuce showed a pronounced yield and quality as affected by $\mathrm{P}$ fertilizer rates (Johnstone et al., 2005). Lettuce was found to have higher requirements of $\mathrm{P}$ fertilizer than most other crops across different soil textures (Hoque et al., 2010). Inadequate supply of $\mathrm{P}$ led to slow down the growth of plants by reducing the water uptake of the root system. The role of $\mathrm{P}$ in enhancing root growth, which in turn improves the ability of crops for phosphate acquisition. Phosphorus application in green beans is known to have a positive effect on enhancing root proliferation and thus enhancing soil water and nutrients uptake (Emam et al., 2018). 
TABLE 4. Effect of fertigation by different levels of $N$ and $P$, and their interaction, on vegetative growth characters and yield of lettuce during the two studied seasons of 2019/2020 and 2020/2021

\begin{tabular}{|c|c|c|c|c|c|c|c|c|}
\hline Variable & P1 & $\mathbf{P 2}$ & P3 & Mean & P1 & P2 & P3 & Mean \\
\hline $1^{\text {st }}$ season & & & \multicolumn{6}{|c|}{$2^{\text {nd }}$ season } \\
\hline \multicolumn{9}{|c|}{ Fresh weight $\left(\mathrm{g}_{\text {plant }}{ }^{-1}\right)$} \\
\hline N1 & $318 \mathrm{~h}$ & $336 \mathrm{~g}$ & $354 f$ & $336 \mathrm{C}$ & $351 \mathrm{f}$ & $369 \mathrm{e}$ & $377 \mathrm{e}$ & $366 \mathrm{C}$ \\
\hline $\mathrm{N} 2$ & $426 \mathrm{e}$ & $486 c$ & $545 b$ & $486 \mathrm{~B}$ & $445 d$ & $506 c$ & $563 b$ & $505 \mathrm{~B}$ \\
\hline N3 & $465 d$ & $547 \mathrm{ab}$ & $554 a$ & $522 \mathrm{~A}$ & $503 c$ & $571 b$ & $596 a$ & $557 \mathrm{~A}$ \\
\hline Mean & $403 \mathrm{C}$ & $457 \mathrm{~B}$ & $485 \mathrm{~A}$ & & $433 \mathrm{C}$ & 482B & $512 \mathrm{~A}$ & \\
\hline \multicolumn{9}{|c|}{ Dry weight $\left(\right.$ g plant $\left.^{-1}\right)$} \\
\hline N1 & $3.60 \mathrm{~g}$ & $4.75 \mathrm{e}$ & $5.11 d$ & $4.49 \mathrm{C}$ & $4.03 \mathrm{~g}$ & $4.17 f$ & $4.20 \mathrm{f}$ & $4.13 \mathrm{C}$ \\
\hline $\mathrm{N} 2$ & $3.75 \mathrm{~g}$ & $5.37 \mathrm{c}$ & $5.71 b$ & $4.94 \mathrm{~B}$ & $5.03 \mathrm{e}$ & $5.66 \mathrm{~d}$ & $5.95 \mathrm{c}$ & $5.55 \mathrm{~B}$ \\
\hline N3 & $3.95 f$ & $6.02 \mathrm{a}$ & $6.12 \mathrm{a}$ & $5.36 \mathrm{~A}$ & $5.69 \mathrm{~d}$ & $6.38 b$ & $6.67 \mathrm{a}$ & $6.25 \mathrm{~A}$ \\
\hline Mean & $3.77 \mathrm{C}$ & $5.38 \mathrm{~B}$ & $5.65 \mathrm{~A}$ & & $4.91 \mathrm{C}$ & $5.41 \mathrm{~B}$ & $5.61 \mathrm{~A}$ & \\
\hline \multicolumn{9}{|c|}{ Plant height $(\mathrm{cm})$} \\
\hline N1 & $16.1 \mathrm{~g}$ & $16.3 \mathrm{fg}$ & $16.5 f$ & $16.3 \mathrm{C}$ & $17.0 \mathrm{~g}$ & $17.9 \mathrm{f}$ & $18.2 \mathrm{f}$ & $17.7 \mathrm{C}$ \\
\hline $\mathrm{N} 2$ & $18.0 \mathrm{e}$ & $18.5 \mathrm{~d}$ & $19.2 \mathrm{c}$ & $18.6 \mathrm{~B}$ & $18.9 \mathrm{e}$ & $19.7 \mathrm{~d}$ & $20.6 \mathrm{c}$ & $19.7 \mathrm{~B}$ \\
\hline N3 & $19.4 \mathrm{c}$ & $20.5 b$ & $21.2 \mathrm{a}$ & $20.4 \mathrm{~A}$ & $21.5 b$ & $21.6 b$ & $22.6 \mathrm{a}$ & $21.9 \mathrm{~A}$ \\
\hline Mean & $17.8 \mathrm{C}$ & $18.4 \mathrm{~B}$ & $19.0 \mathrm{~A}$ & & $19.1 \mathrm{C}$ & $19.7 \mathrm{~B}$ & $20.4 \mathrm{~A}$ & \\
\hline \multicolumn{9}{|c|}{ Stem diameter $(\mathrm{cm})$} \\
\hline N1 & $11.4 \mathrm{~h}$ & $11.6 \mathrm{~h}$ & $11.9 \mathrm{~g}$ & $11.6 \mathrm{C}$ & $12.4 \mathrm{~h}$ & $12.7 \mathrm{~g}$ & $12.9 \mathrm{~g}$ & $12.7 \mathrm{C}$ \\
\hline $\mathrm{N} 2$ & $13.5 f$ & $14.7 \mathrm{~d}$ & $15.7 b$ & $14.6 \mathrm{~B}$ & $14.8 \mathrm{f}$ & $16.1 \mathrm{~d}$ & $17.2 \mathrm{~b}$ & $16.0 \mathrm{~B}$ \\
\hline N3 & $14.0 \mathrm{e}$ & $15.2 \mathrm{c}$ & $16.0 \mathrm{a}$ & $15.1 \mathrm{~A}$ & $15.4 \mathrm{e}$ & $16.6 \mathrm{c}$ & $17.5 \mathrm{a}$ & $16.5 \mathrm{~A}$ \\
\hline Mean & $13.0 \mathrm{C}$ & $13.8 \mathrm{~B}$ & $14.5 \mathrm{~A}$ & & $14.2 \mathrm{C}$ & $15.1 \mathrm{~B}$ & $15.9 \mathrm{~A}$ & \\
\hline \multicolumn{9}{|c|}{ No. of leaves per plant } \\
\hline N1 & $16.8 \mathrm{i}$ & $17.1 \mathrm{~h}$ & $19.0 \mathrm{~g}$ & $17.6 \mathrm{C}$ & $18.3 \mathrm{~g}$ & $19.4 \mathrm{f}$ & $20.4 \mathrm{e}$ & $19.4 \mathrm{C}$ \\
\hline $\mathrm{N} 2$ & $22.5 f$ & $23.5 \mathrm{e}$ & $26.1 \mathrm{c}$ & $24.1 \mathrm{~B}$ & $23.9 \mathrm{~d}$ & $25.3 \mathrm{c}$ & $28.0 \mathrm{~b}$ & $25.7 \mathrm{~B}$ \\
\hline N3 & $24.3 \mathrm{~d}$ & $26.6 b$ & $29.0 \mathrm{a}$ & $26.6 \mathrm{~A}$ & $25.3 \mathrm{c}$ & $27.7 b$ & $30.1 \mathrm{a}$ & $27.7 \mathrm{~A}$ \\
\hline Mean & $21.2 \mathrm{C}$ & $22.4 \mathrm{~B}$ & $24.7 \mathrm{~A}$ & & $22.5 \mathrm{C}$ & $24.1 \mathrm{~B}$ & $26.2 \mathrm{~A}$ & \\
\hline \multicolumn{9}{|c|}{ Chlorophyll (SPAD) } \\
\hline N1 & $26.0 \mathrm{~g}$ & $27.1 \mathrm{f}$ & $27.4 f$ & $26.9 \mathrm{C}$ & $28.2 \mathrm{~g}$ & $29.8 \mathrm{f}$ & $29.8 \mathrm{f}$ & $29.3 \mathrm{C}$ \\
\hline $\mathrm{N} 2$ & $38.1 \mathrm{e}$ & $39.7 d$ & $41.8 \mathrm{c}$ & $39.8 \mathrm{~B}$ & $36.9 \mathrm{e}$ & $42.9 \mathrm{c}$ & $44.7 \mathrm{~b}$ & $41.5 \mathrm{~B}$ \\
\hline N3 & $42.3 b c$ & $42.9 \mathrm{~b}$ & $44.0 \mathrm{a}$ & $43.1 \mathrm{~A}$ & $42.1 \mathrm{~d}$ & $46.9 \mathrm{a}$ & $46.6 \mathrm{a}$ & $45.2 \mathrm{~A}$ \\
\hline Mean & $35.5 \mathrm{C}$ & $36.6 \mathrm{~B}$ & $37.7 \mathrm{~A}$ & & $35.7 \mathrm{C}$ & $39.9 \mathrm{~B}$ & $40.3 \mathrm{~A}$ & \\
\hline \multicolumn{9}{|c|}{ Yield (g plant $\left.{ }^{-1}\right)$} \\
\hline N1 & $485 \mathrm{~h}$ & $505 \mathrm{~g}$ & $526 f$ & $506 \mathrm{C}$ & $527 \mathrm{~h}$ & $547 \mathrm{~g}$ & $565 f$ & $546 \mathrm{C}$ \\
\hline $\mathrm{N} 2$ & $636 \mathrm{e}$ & $744 c$ & $824 b$ & $735 \mathrm{~B}$ & $687 \mathrm{e}$ & $804 c$ & $893 b$ & $795 B$ \\
\hline N3 & $699 d$ & $818 b$ & $869 a$ & $796 \mathrm{~A}$ & $751 d$ & $886 b$ & $945 \mathrm{a}$ & $861 \mathrm{~A}$ \\
\hline Mean & $607 \mathrm{C}$ & 689B & $740 \mathrm{~A}$ & & $655 \mathrm{C}$ & $746 \mathrm{~B}$ & $801 \mathrm{~A}$ & \\
\hline
\end{tabular}

Note: $\mathrm{N} 1\left(60 \mathrm{mg} \mathrm{L}^{-1}\right), \mathrm{N} 2\left(120 \mathrm{mg} \mathrm{L}^{-1}\right)$ and N3 $\left(180 \mathrm{mg} \mathrm{L}^{-1}\right)$ in the form of $\mathrm{NH}_{4} \mathrm{NO}_{3}$; and P1 $\left(15 \mathrm{mg} \mathrm{L}^{-1}\right), \mathrm{P}^{2}$ (35 $\left.\mathrm{mg} \mathrm{L}^{-1}\right)$ and $\mathrm{P} 3\left(55 \mathrm{mg} \mathrm{L}^{-1}\right)$ in the form of $\mathrm{H}_{3} \mathrm{PO}_{4}$, added to the soil by fertigation system. Different letters mean significant at $5 \%$ level. 


\section{Nutrient content in leaves}

Regarding to the effect of $\mathrm{N}$ levels, data in Table 5 showed that using $180 \mathrm{mg} \mathrm{N} \mathrm{L}^{-1}$ led to increase the content of $\mathrm{N}, \mathrm{P}, \mathrm{K}, \mathrm{Ca}$ and $\mathrm{Mg}$ significantly in the dry weight of lettuce leaves followed by $120 \mathrm{mg} \mathrm{N} \mathrm{L} \mathrm{m}^{-1}$ with significant difference between them. The lowest content of the studied macro-nutrients was obtained by applying $60 \mathrm{mg} \mathrm{N} \mathrm{L}^{-1}$.

Data in Table 5, also, showed the effect of different $\mathrm{P}$ levels on the content of the studied macro-nutrients of lettuce leaves during the two investigated seasons. The highest content was observed by applying $55 \mathrm{mg} \mathrm{L}^{-1}$ followed by $35 \mathrm{mg}$ $\mathrm{L}^{-1} \mathrm{P}$ during both seasons. While the lowest ones were obtained by applying $15 \mathrm{mg} \mathrm{P} \mathrm{L}^{-1}$. Regarding the interaction effect between $\mathrm{N}$ and $\mathrm{P}$ levels, data showed that using $180 \mathrm{mg} \mathrm{N} \mathrm{L}^{-1}$ combined with $55 \mathrm{mg} \mathrm{P} \mathrm{L}{ }^{-1}$ increased the plant content of the studied macro-nutrients. While the lowest ones preceded by applying $60 \mathrm{mg} \mathrm{N} \mathrm{L}^{-1}$ with $15 \mathrm{mg} \mathrm{P}$ $\mathrm{L}^{-1}$. Similar results were obtained by Farag et al. (2013) who stated that increase $\mathrm{N}$ dose for lettuce led to increase the plants uptake from N, P, K, Ca and $\mathrm{Mg}$ through enhancing the plants metabolism and then increase plant needs for absorb more nutrients. On the other hands, $\mathrm{P}$ played a positive effect on enhancing root proliferation and thus enhancing nutrients uptake (Emam et al., 2018).

\section{Nitrate accumulation}

Regarding nitrate content, data indicated that increased $\mathrm{N}$ level led to concurrent increase in nitrate content during both seasons (Table 5). While $\mathrm{P}$ had another trend, increasing P level up to $55 \mathrm{mg} \mathrm{L}^{-1}$ led to decrease nitrate content in produced lettuce heads. Many researchers have demonstrated that applying $\mathrm{N}$ fertilizers increased accumulation of $\mathrm{NO}_{3}^{-}$in plant leaves (Hoque et al., 2010; Corradini et al., 2018; Tabaglio et al., 2020). The European Union set limits from 3500 to $4500 \mathrm{mg} \mathrm{NO}_{3}^{-} \mathrm{kg}^{-1}$ of lettuce fresh leaves for the winter season and $2500 \mathrm{mg} \mathrm{NO}_{3}^{-} \mathrm{kg}^{-1}$ for the summer crops (Anon, 2011). However, the EU set the acceptable daily intake of $\mathrm{NO}_{3}^{-}$at $0-3.7 \mathrm{mg}$ $\mathrm{kg}^{-1}$ bodyweight (Anon, 2011). According to these limits, $\mathrm{NO}_{3}{ }^{-}$concentrations in lettuce leaves were sufficient. But the threat is found by continuing application with excess amount of $\mathrm{N}$ fertilizers, which will certainly lead to nitrate pollution.

These results agreed with those obtained by Wang et al. (2008) who stated that higher $\mathrm{N}$ doses increased the ${\mathrm{N}-\mathrm{NO}_{3}}_{3}^{-}$concentration in lettuce

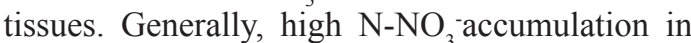
leafy vegetables is expected due to harvesting at the vegetative growth stage. As the concentration of $\mathrm{P}$ increased, the nitrate levels in lettuce leaves decreased. Phosphorus levels are linked to nitrate uptake and metabolism. Increasing P concentration in plant cells led to significant increase in nitrate reductase activity and then decline of nitrate content (Buwalda and Warmenhoven, 1999; Ahmed et al., 2000).

Accumulation rate of $\mathrm{NO}_{3}^{-}$in lettuce leaves as influenced by $\mathrm{N}$ and $\mathrm{P}$ levels under fertigation system and their interaction are illustrated in Figs. 1, 2 and 3. Despite the similarity of the applied different $\mathrm{N}$ levels in total $\mathrm{NO}_{3}^{-}$accumulation in lettuce leaves, tending to relatively reduce accumulation with applying $\mathrm{N} 1\left(60 \mathrm{mg} \mathrm{L}^{-1}\right)$ without any significant difference between this application and the other applications of $\mathrm{N}$ level. Logically, supply lettuce plants with $\mathrm{N}$; increases $\mathrm{N}$ accumulation in plant leaves (Fig. 1).

Regarding the $\mathrm{P}$ levels, the rate of $\mathrm{NO}_{3}^{-}$ accumulation associated with application of P1 (15 $\mathrm{mg} \mathrm{L}^{-1}$ ) was higher than the other levels of applied $\mathrm{P}$, with significant difference between them (Fig. $2)$. It may be due to that $P$ in high levels increases nitrate reductase activity, so, decreases $\mathrm{NO}_{3}^{-}$ accumulation inside the plant tissues (Buwalda and Warmenhoven, 1999; Ahmed et al., 2000). However, the difference in $\mathrm{NO}_{3}^{-}$accumulation due to the interaction between $\mathrm{N}$ and $\mathrm{P}$ levels (Fig. 3 ) were significant in most of cases, with high rate that achieved by the treatment of $\mathrm{N} 3 \times \mathrm{P} 1$, on the other hand, the low rate was achieved by $\mathrm{N} 1 \times \mathrm{P} 3$ treatment. 
TABLE 5. Effect of fertigation by different levels of $N$ and $P$, and their interaction, on nutrient content of lettuce leaves during the two studied seasons of 2019/2020 and 2020/2021

\begin{tabular}{|c|c|c|c|c|c|c|c|c|}
\hline Variable & P1 & $\mathbf{P 2}$ & P3 & Mean & $\mathbf{P 1}$ & P2 & P3 & Mean \\
\hline $1^{\text {st }}$ season & & & & & \multicolumn{4}{|c|}{$2^{\text {nd }}$ season } \\
\hline \multicolumn{9}{|l|}{$\mathrm{N}\left(\mathrm{g} \mathrm{kg}^{-1}\right)$} \\
\hline N1 & $18.3 \mathrm{~g}$ & $19.8 \mathrm{f}$ & $20.5 f$ & $19.5 \mathrm{C}$ & $18.8 \mathrm{~g}$ & $18.9 \mathrm{~g}$ & $20.5 f$ & $19.4 \mathrm{C}$ \\
\hline N2 & $24.3 \mathrm{e}$ & $24.8 \mathrm{de}$ & $25.4 \mathrm{~d}$ & $24.8 \mathrm{~B}$ & $24.1 \mathrm{e}$ & $25.9 \mathrm{~d}$ & $25.8 \mathrm{~d}$ & $25.3 \mathrm{~B}$ \\
\hline N3 & $27.9 \mathrm{c}$ & $29.5 b$ & $30.9 \mathrm{a}$ & $29.4 \mathrm{~A}$ & $28.7 \mathrm{c}$ & $29.1 b$ & $31.5 \mathrm{a}$ & $29.8 \mathrm{~A}$ \\
\hline Mean & $23.5 \mathrm{C}$ & $24.7 \mathrm{~B}$ & $25.6 \mathrm{~A}$ & & $23.9 \mathrm{C}$ & $24.6 \mathrm{~B}$ & $25.9 \mathrm{~A}$ & \\
\hline \multicolumn{9}{|l|}{$\mathrm{P}\left(\mathrm{g} \mathrm{kg}^{-1}\right)$} \\
\hline N1 & $2.40 \mathrm{f}$ & $3.60 \mathrm{~d}$ & $4.01 \mathrm{bc}$ & $3.34 \mathrm{C}$ & $2.45 f$ & $3.58 \mathrm{~d}$ & $3.99 \mathrm{bc}$ & $3.34 \mathrm{C}$ \\
\hline N2 & $2.6 \mathrm{ef}$ & $3.87 \mathrm{c}$ & $4.67 \mathrm{a}$ & $3.71 \mathrm{~B}$ & $2.60 \mathrm{f}$ & $3.82 \mathrm{~cd}$ & $4.73 a$ & $3.72 \mathrm{~B}$ \\
\hline N3 & $2.81 \mathrm{e}$ & $4.14 b$ & $4.83 a$ & $3.93 \mathrm{~A}$ & $3.02 \mathrm{e}$ & $4.22 \mathrm{~b}$ & $4.78 \mathrm{a}$ & $4.01 \mathrm{~A}$ \\
\hline Mean & $2.60 \mathrm{C}$ & $3.87 \mathrm{~B}$ & $4.50 \mathrm{~A}$ & & $2.69 \mathrm{C}$ & $3.87 \mathrm{~B}$ & $4.50 \mathrm{~A}$ & \\
\hline \multicolumn{9}{|l|}{$\mathrm{K}\left(\mathrm{g} \mathrm{kg}^{-1}\right)$} \\
\hline N1 & $26.2 f$ & $27.8 \mathrm{ef}$ & $28.4 \mathrm{de}$ & $27.5 \mathrm{C}$ & $27.5 \mathrm{~d}$ & $26.7 \mathrm{~d}$ & $28.4 \mathrm{c}$ & $27.5 \mathrm{~B}$ \\
\hline N2 & $29.8 \mathrm{~cd}$ & $32.7 b$ & $31.8 \mathrm{~b}$ & $31.4 \mathrm{~B}$ & $29.0 \mathrm{c}$ & $31.7 \mathrm{~b}$ & $32.6 a b$ & $31.1 \mathrm{~A}$ \\
\hline $\mathrm{N} 3$ & $31.6 \mathrm{bc}$ & $35.5 \mathrm{a}$ & $36.9 \mathrm{a}$ & $34.7 \mathrm{~A}$ & $31.7 \mathrm{~b}$ & $33.6 \mathrm{a}$ & $28.4 \mathrm{c}$ & $31.2 \mathrm{~A}$ \\
\hline Mean & $29.2 \mathrm{~B}$ & $32.0 \mathrm{~A}$ & $32.4 \mathrm{~A}$ & & $29.4 \mathrm{~B}$ & $30.7 \mathrm{AB}$ & $29.8 \mathrm{~A}$ & \\
\hline \multicolumn{9}{|c|}{$\mathrm{Ca}\left(\mathrm{g} \mathrm{kg}^{-1}\right)$} \\
\hline N1 & $16.3 \mathrm{e}$ & $16.8 \mathrm{e}$ & $17.2 \mathrm{de}$ & $16.8 \mathrm{~B}$ & $18.1 \mathrm{c}$ & $18.5 \mathrm{bc}$ & $18.8 \mathrm{~b}$ & $18.5 \mathrm{C}$ \\
\hline N2 & $16.6 \mathrm{e}$ & $17.9 \mathrm{~d}$ & $18.5 \mathrm{~cd}$ & $17.7 \mathrm{~B}$ & $19.1 \mathrm{~b}$ & $20.8 \mathrm{a}$ & $21.3 \mathrm{a}$ & $20.4 \mathrm{~B}$ \\
\hline N3 & $19.4 b c$ & $20.5 b$ & $24.0 \mathrm{a}$ & $21.3 \mathrm{~A}$ & $21.6 \mathrm{a}$ & $21.5 \mathrm{a}$ & $22.2 \mathrm{a}$ & $21.8 \mathrm{~A}$ \\
\hline Mean & $17.4 \mathrm{~B}$ & $18.4 \mathrm{~B}$ & $19.9 \mathrm{~A}$ & & $19.6 \mathrm{~B}$ & $20.3 \mathrm{~A}$ & $20.8 \mathrm{~A}$ & \\
\hline \multicolumn{9}{|c|}{$\operatorname{Mg}\left(\mathrm{g} \mathrm{kg}^{-1}\right)$} \\
\hline N1 & $2.42 \mathrm{c}$ & $4.26 \mathrm{~b}$ & $4.31 \mathrm{~b}$ & $3.66 \mathrm{C}$ & $3.53 \mathrm{~d}$ & $3.62 \mathrm{~d}$ & $3.77 \mathrm{~d}$ & $3.64 \mathrm{C}$ \\
\hline $\mathrm{N} 2$ & $4.44 b$ & $4.71 \mathrm{~b}$ & $4.86 \mathrm{ab}$ & $4.67 \mathrm{~B}$ & $4.38 \mathrm{c}$ & $4.84 b$ & $4.73 b$ & $4.65 \mathrm{~B}$ \\
\hline $\mathrm{N} 3$ & $4.91 \mathrm{ab}$ & $5.07 \mathrm{a}$ & $5.69 \mathrm{a}$ & $5.22 \mathrm{~A}$ & $4.88 \mathrm{~b}$ & $4.87 \mathrm{~b}$ & $5.67 \mathrm{a}$ & $5.14 \mathrm{~A}$ \\
\hline Mean & $3.92 \mathrm{~B}$ & $4.68 \mathrm{~A}$ & $4.95 \mathrm{~A}$ & & 4.26B & $4.45 \mathrm{~B}$ & $4.72 \mathrm{~A}$ & \\
\hline \multicolumn{9}{|c|}{$\mathrm{NO}_{3}^{-}\left(\mathrm{mg} \mathrm{kg}^{-1}\right)$} \\
\hline N1 & $662 \mathrm{~g}$ & $582 \mathrm{~h}$ & $533 i$ & $592 \mathrm{C}$ & $676 \mathrm{~g}$ & $569 \mathrm{~h}$ & $546 \mathrm{i}$ & $597 \mathrm{C}$ \\
\hline N2 & $923 c$ & $805 \mathrm{e}$ & $720 f$ & 816B & $895 \mathrm{c}$ & $816 \mathrm{e}$ & $699 f$ & 803B \\
\hline N3 & $1214 \mathrm{a}$ & $1015 b$ & $824 d$ & $1018 \mathrm{~A}$ & $1237 \mathrm{a}$ & $990 \mathrm{~b}$ & $849 d$ & $1026 \mathrm{~A}$ \\
\hline Mean & $933 \mathrm{~A}$ & 801B & $693 \mathrm{C}$ & & $936 \mathrm{~A}$ & 791B & $698 \mathrm{C}$ & \\
\hline
\end{tabular}

See footnotes of Table 4 . 


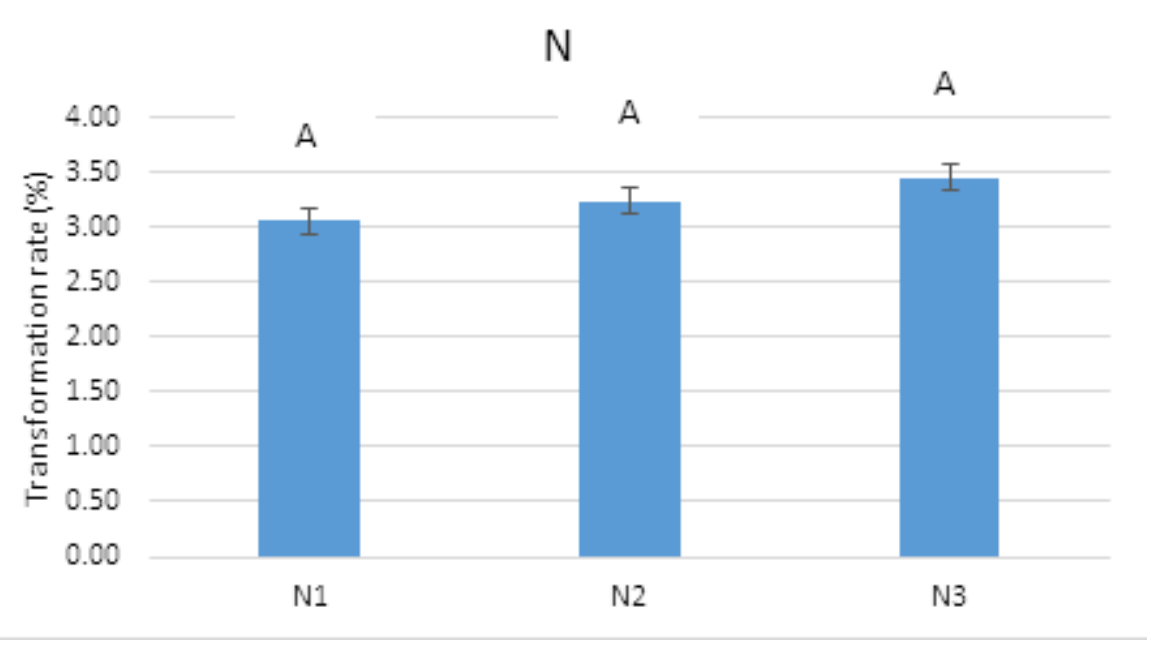

Fig. 1. Effect of $\mathrm{N}$ levels on $\mathrm{NO}_{3}^{-}$transformation rate in lettuce (the average of mean values of the two studied seasons)

Note: $\mathrm{N} 1\left(60 \mathrm{mg} \mathrm{L}^{-1}\right), \mathrm{N} 2\left(120 \mathrm{mg} \mathrm{L}^{-1}\right)$ and N3 $\left(180 \mathrm{mg} \mathrm{L}^{-1}\right)$ in the form of $\mathrm{NH}_{4} \mathrm{NO}_{3}$, added to the soil by fertigation system. Different letters mean significant at $5 \%$ level.

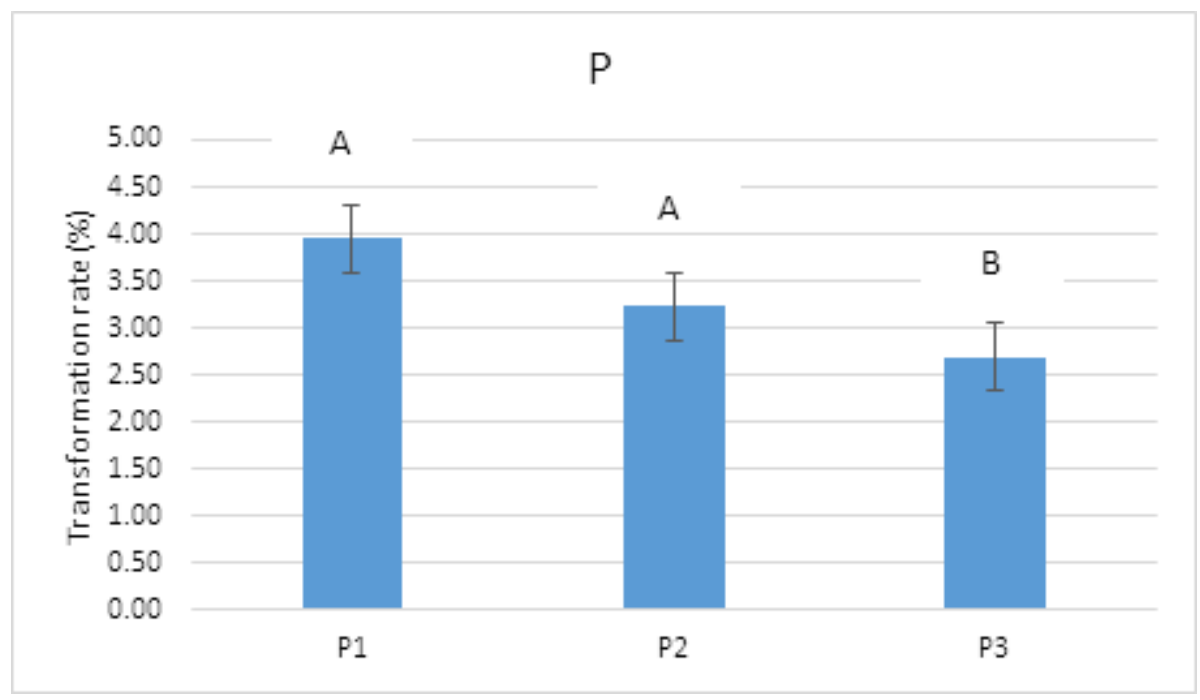

Fig. 2. Effect of $\mathrm{P}$ levels on $\mathrm{NO}_{3}^{-}$transformation rate in lettuce (the average of mean values of the two studied seasons)

Note: P1 (15 mg L-1), P2 (35 mg L-1) and P3 $\left(55 \mathrm{mg} \mathrm{L}^{-1}\right)$ in the form of $\mathrm{H}_{3} \mathrm{PO}_{4}$, added to the soil by fertigation system. Different letters mean significant at 5\% level.

Egypt. J. Soil Sci. 61, No. 2 (2021) 


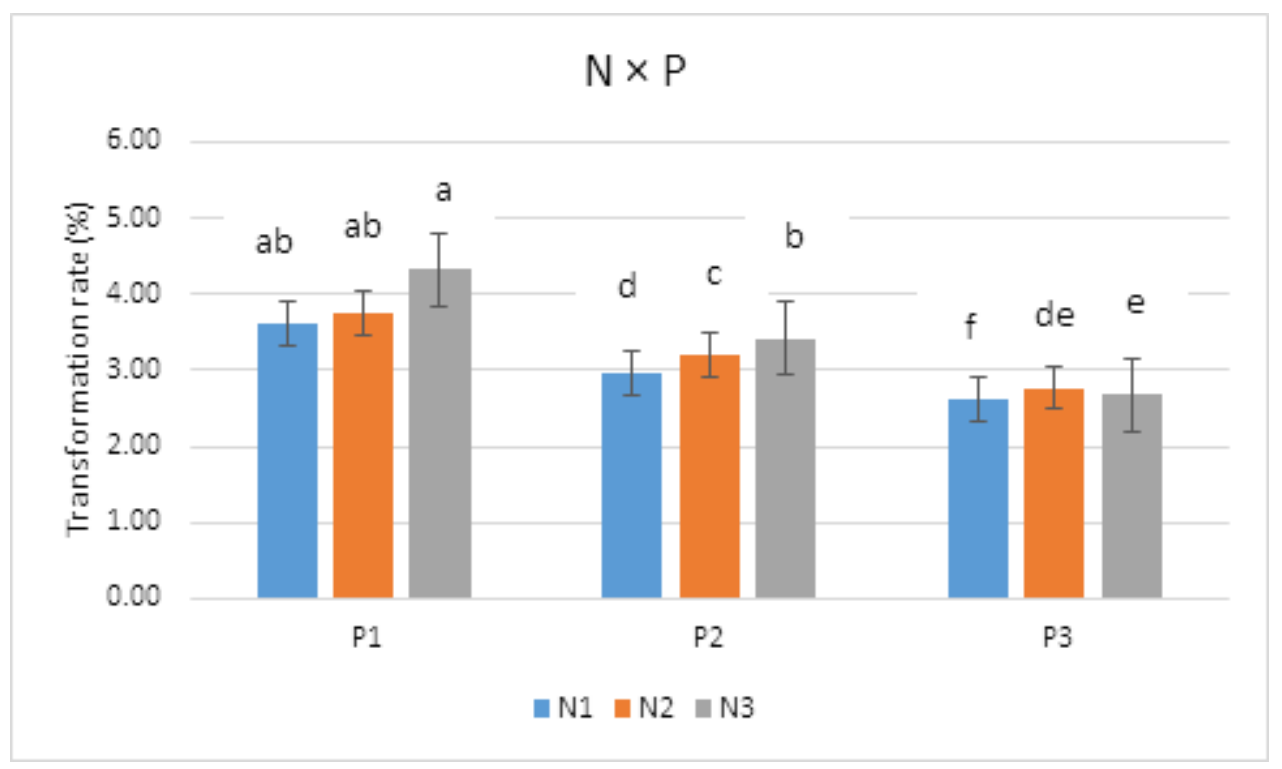

Fig. 3. Effect of $\mathrm{N}$ and $\mathrm{P}$ levels interaction on $\mathrm{NO}_{3}^{-}$transformation rate in lettuce (the average of mean values of the two studied seasons)

Note: N1 (60 mg L L $)$, N2 (120 mg L-1) and N3 (180 mg L $\left.\mathrm{m}^{-1}\right)$ in the form of $\mathrm{NH}_{4} \mathrm{NO}_{3}$; and P1 $\left(15 \mathrm{mg} \mathrm{L}^{-1}\right), \mathrm{P} 2\left(35 \mathrm{mg} \mathrm{L}^{-1}\right)$ and P3 $\left(55 \mathrm{mg} \mathrm{L}^{-1}\right)$ in the form of $\mathrm{H}_{3} \mathrm{PO}_{4}$, added to the soil by fertigation system. Different letters mean significant at $5 \%$ level.

\section{Conclusion}

Working on nutrient equilibrium, especially macro-nutrients inside the plant, is important for good and healthy production of crops. The main problem of $\mathrm{N}$ fertilization, especially for leafy crops, lies in the accumulation of nitrates within plant tissues, which causes severe damage to human health and environmental problems. The solution is to add this nutrient in balanced quantities without extravagance, considering its relationship with the rest of the other nutrients, especially $\mathrm{P}$. The results of this study indicated that increase $\mathrm{N}$ supplies up to $180 \mathrm{mg} \mathrm{L}^{-1}$ led to increase the vegetative characters, yield and elemental content of lettuce plants. Regarding the $\mathrm{P}$ additions, increasing $\mathrm{P}$ supply up to $55 \mathrm{mg}$ $\mathrm{L}^{-1}$ increased growth and productivity of plants during both studied seasons. Interaction effect between $\mathrm{N}$ and $\mathrm{P}$ levels indicated that $180 \mathrm{mg} \mathrm{N}$ $\mathrm{L}^{-1}$ combined with $55 \mathrm{mg} \mathrm{P} \mathrm{L}^{-1}$ gave the highest lettuce productivity followed by $180 \mathrm{mg} \mathrm{N} \mathrm{L}^{-1}$ combined with $35 \mathrm{mg} \mathrm{P} \mathrm{L}^{-1}$. While increase $\mathrm{P}$ level led to decrease $\mathrm{NO}_{3}^{-}$concentration and accumulation rate of nitrate in plant tissues.

\section{References}

Ahmed, A.H.H., Khalil, M.K. and Farrag, A.M. (2000) Nitrate accumulation, growth, yield and chemical composition of Rocket (Eruca vesicaria subsp. sativa) plant as affected by NPK fertilization, kinetin and salicylic acid. In: Proceedings of ICEHM 2000, Cairo University, Egypt, pp. 495508.

Anon (2011) Commission Regulation (EU) No. 1258/2011 of 2 December 2011 amending Regulation (EC) No. 1881/2006 as regards maximum levels for nitrates in foodstuffs. Off. $J$. Eur. Union, L320, 15-17.

Burns, I.G. (1996) Nitrogen supply, growth and development. Acta Hort. 428, 21-30.

Buwalda, F. andWarmenhoven, M. (1999) Growthlimiting phosphate nutrition suppresses nitrate accumulation in greenhouse lettuce. J. Exp. Bot. 50, 813-821.

Chapman, H.D. and Pratt, P.F. (1961) Methods of Analysis for Soils, Plants and Waters. USA: California, Division of Agric. Sci., Berkeley Univ., 150-152. 
Corradini, F., Correa, A., Moyano, M.S., Sepúlveda, P., Quiroz, C. (2018) Nitrate, arsenic, cadmium, and lead concentrations in leafy vegetables: Expected average values for productive regions of Chile. Arch. Agron. Soil Sci. 64, 299-317. doi:10.1080/0 3650340.2017 .1346790

Cottenie, A., Verloo, M., Kiekens, L., Velgh, G. and Camerlynech, R. (1982) Chemical Analysis of Plants and Soils. Belgium: Ghent, State Univ.

Derderian, M.D. (1961) Determination of calcium and magnesium in plant material with EDTA. Anal. Chem.33 (12), 1796-1798.

Djidonou, D. and Leskovar, D.I. (2019) Seasonal changes in growth, nitrogen nutrition, and yield of hydroponic lettuce. HortSci. 54, 76-85. doi:10.21273/hortsci13567-18

Du, H.X., Wu, P. and Wang, B.Q. (2009) Influence of applying phosphorus on soil nitrate $\mathrm{N}$ and nutrient uptake and yield of summer maize. J. Northwest Agric. Forest. Univ. (Natural Science Edition), 37 (8), 121-126.

Elbasiouny, H. and Elbehiry, F. (2019) Soil carbon and nitrogen stocks and fractions for improving soil quality and mitigating climate change: Review. Egypt. J. Soil Sci. 59 (2), 131-144.

El-Dissoky, R.A. (2019) Mixed and conventional nitrogen fertilizers impacts on yield, quality and nutrient uptake by potato. Egypt. J. Soil Sci. 59 (3), 259-274.

Emam, M.S.A., Abd El-Rahman, N.G. and Abdrabbo, M.A.A.(2018) Evaluation of natural and chemical phosphorus fertilizers on plant growth, and yield of some green beans cultivars. Annals Agric. Sci., Moshtohor, 56, 349-358. doi:10.21608/ assjm.2018.116144

Farag, A.A. and Abd-Elrahman, Shaimaa H. (2016) Greenhouse gas emission from cauliflower grown under different nitrogen rates and mulches. Int. J. Plant Soil Sci.9 (1), 1-10. http://dx.doi.org/10.9734/ IJPSS/2016/19880

Farag, A.A.A., Abdrabbo, M.A.A. and Abd-Elmoniem, E.M. (2013) Using different nitrogen and compost levels on lettuce grown in coconut fiber. J. Hort. Forest. 5 (2), 21-28.

Hammouda, I.A., Elbaalawy, A.M. and El-Feishy, M.A. (2019) Effect of compost additives and application time of phosphorus in different methods on growth, productivity and quality of peanut in sandy soils. Egypt. J. Soil Sci. 59 (4), 339-352.
Heidari, M. and Mohammad, M.M. (2012) Effect of rate and time of nitrogen application on fruit yield and accumulation of nutrient elements in Momordica charantia. J. Saudi Soc. Agric. Sci. 11, 129-133. doi:10.1016/j.jssas.2012.02.003

Hoque, M.M., Ajwa, H. and Othman, M. (2010) Yield and postharvest quality of lettuce in response to nitrogen, phosphorus, and potassium fertilizers. HortSci. 45 (10), 1539-1544.

Johnstone, P.R., Hartz, T.K.,Cahn, M.D. and Johnstone, M.R. (2005) Lettuce response to phosphorus fertilization in high phosphorus soils. HortSci. 40, 1499-1503.

Khalifa, R.M. (2019) Response of faba bean to alternate irrigation and cut-off irrigation combined with mineral phosphorus levels and biofertilizer at North Nile Delta soils. Egypt. J. Soil Sci. 59 (2), 175-191.

Liao, L., Dong, T., Liu, X., Dong, Z., Qiu, X., Rong, Y., et al. (2019) Effect of nitrogen supply on nitrogen metabolism in the citrus cultivar 'Huangguogan'. PLOS ONE 14 (5), e0216639. https://doi. org/10.1371/journal.pone.0216639

Minolta (1989) Chlorophyll meter SPAD-502, Instruction Manual. Minolta Co., Ltd., Radiometric Instruments Operations, Japan: Osaka.

Moursy, M.A.M., Emara, E.I.R., Abd El-Hamid, S.G. and Hamed, L.M.M. (2019) Response of Allium crops to nitrogen fertilization rates and different irrigation water sources. Egypt. J. Soil Sci. 59 (2), 193-205.

Parente, A., Gonnella, M.,Santamaria, P.,L'Abbate, P.,Conversa, G. and Elia, A. (2006) Nitrogen fertilization of new cultivars of lettuce. Acta Hort. 700, 137-140.

Prasad, S. and Chetty, A.A. (2008) Nitrate-N determination in leafy vegetables: Study of the effects of cooking and freezing. Food Chem. 106, $772-780$

Razaq, M., Zhang, P., Shen H. and Salahuddin (2017) Influence of nitrogen and phosphorous on the growth and root morphology of Acer mono. PLOS ONE 12, e0171321. doi:10.1371/journal. pone. 0171321

Sadeghi, P.M.M.,Hasan, P.J. and Nasri, M. (2009) Effect of different levels of nitrogen and phosphorous fertilizers on nitrate accumulation and agronomic characteristics in lettuce. Pajouhesh\&Sazandegi, 21, 107-112. 
Saleh, S.A., Zaki, M.F.,Tantawy, A.S. and Salama, Y.A. (2016) Response of Artichoke productivity to different proportions of nitrogen and potassium fertilizers. Int. J. ChemTech. Res. 9 (3), 25-33.

Sarkar, M.D., Rahman, M.J.,Uddain, J.,Quamruzzaman, M., Azad, M.O.K., Rahman, M.H., et al. (2021) Estimation of yield, photosynthetic rate, biochemical, and nutritional content of red leaf lettuce (Lactuca sativa L.) grown in organic substrates. Plants, 10, 1220. https://doi. org/10.3390/plants 10061220

SAS Institute (2006) The SAS system for windows; Statistical Analysis System Institute Inc., USA: Cary, North Carolina.

Schenk, M.K. (2006) Nutrient efficiency of vegetable crops. Acta Hort. 700, 21-33.

Soil Survey Staff. (2010) Keys to Soil Taxonomy ( $11^{\text {th }}$ ed.). Washington, DC: U.S. Department of Agriculture, Natural Resources Conservation Service, U.S. Government Printing Office.
Abd-Elrahman, Shaimaa H. and Gad-Elmoula, Manal M.H. (2017) Effect of non-classic nitrogen fertilizers on soil chemical properties, growth of zucchini plants and $\mathrm{N}_{2} \mathrm{O}$ emission. Asian J. Soil Sci. Plant Nutr. 1 (2), 1-10. http://dx.doi.org/10.9734/ AJSSPN/2017/35141

Tabaglio, V., Boselli, R.,Fiorini, A.,Ganimede, Cristina, Beccari, P., Santelli, S. and Nervo, G. (2020) Reducing nitrate accumulation and fertilizer use in lettuce with modified intermittent nutrient film technique (NFT) system. Agron. 10, 1-15. https:// doi.org/10.3390/agronomy10081208

Wang, Z.H., Li, S. and Malhi, S. (2008) Effects of fertilization and other agronomic measures on nutritional quality of crops. J. Sci. Food Agric. 88, $7-23$.

Watanabe, F.C. and Olsen, S.R. (1965) Test of an ascorbic acid method for determining phosphorus in water and $\mathrm{NaHCO}_{3}$ extracts from soils. Soil Sci. Soc. Amer. Proc. 29, 677-678. 


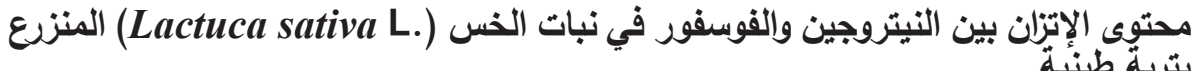

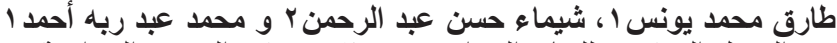

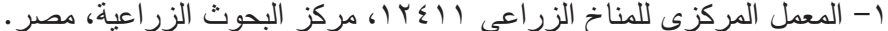

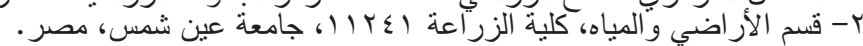

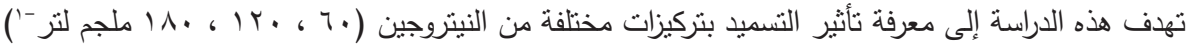

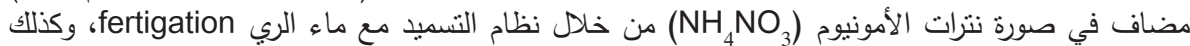

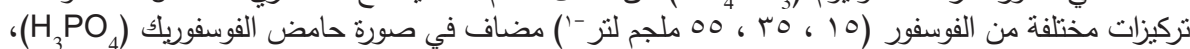

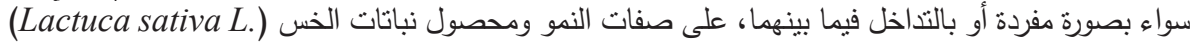

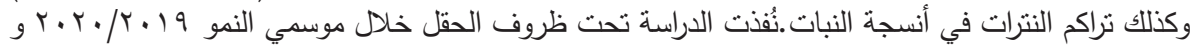

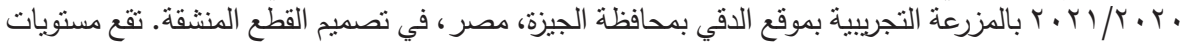

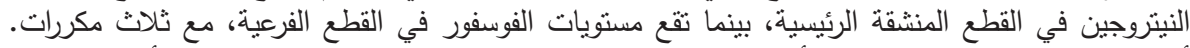

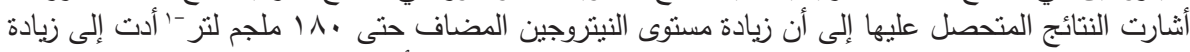

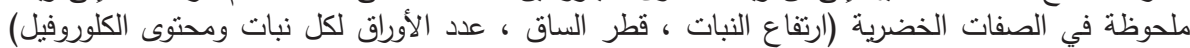

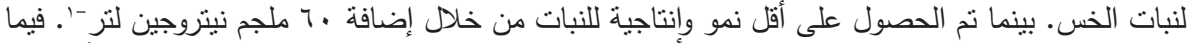

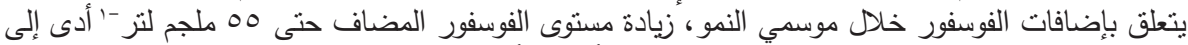

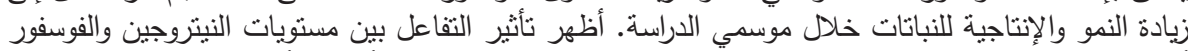

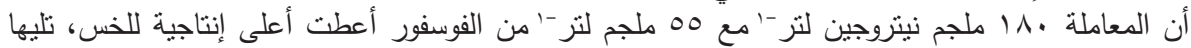

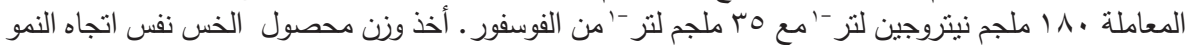

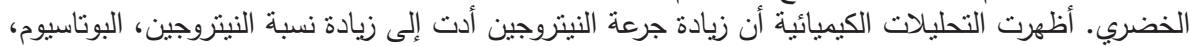

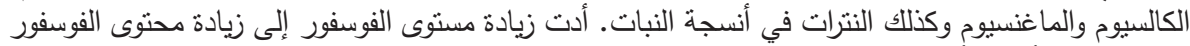
داخل النبات. أخيرًا، أدت زيادة مستوى الفوسفور إلى انخفاض تركيز النيتروجين في صورة النترات ومعدل نراكم النترات في أنسجة النبات. 